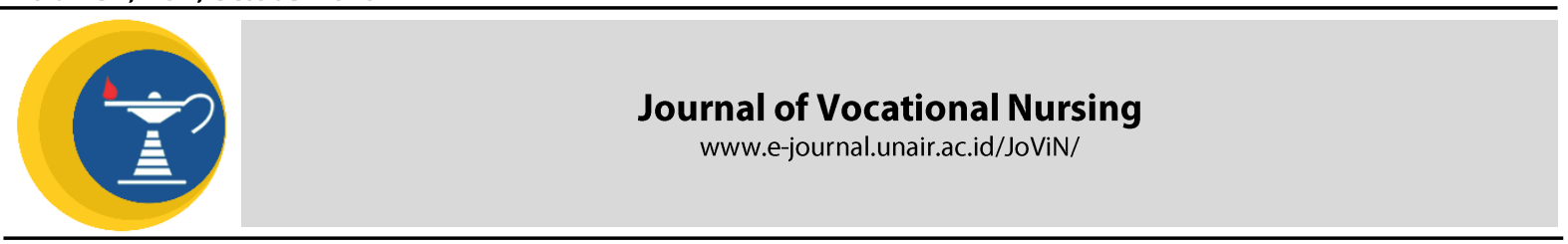

\title{
ANALYSIS OF KNOWLEDGE AND MOTIVATION OF SEBAYA COUNSELERS IN THE IMPLEMENTATION OF ADOLESCENT REPRODUCTIVE HEALTH COUNSELING IN SUMENEP DISTRICT
}

\author{
Research Report
}

\author{
Dian Permatasari \\ DIII Kebidanan Universitas Wiraraja Sumenep
}

\section{ABSTRACT}

Introduction: The globalization of information has a big impact on adolescents. The great curiosity of adolescents about reproduction encourages adolescents to seek information from various sources, including peers, parents, schools and information media. This requires correct and responsible information so that adolescents can have healthy reproductive behavior. The aim is to analyze the knowledge and motivation of peer counselors in the implementation of adolescent reproductive health counseling in Sumenep Regency. Methods: This study used quantitative methods with cross sectional design. The population in this study is the total population, namely all peer counselors who have received training on Adolescent Reproductive Health in Sumenep Regency as many as 66 people. Sampling technique using simple random sampling. Data analysis used chisquare statistical test and logistic regression. Results: The results showed that knowledge about adolescent reproductive health counseling, motivation towards the implementation of adolescent reproductive health counseling, had an influence on the implementation of adolescent reproductive health counseling. Conclusion: This study recommends the Sumenep Regency $B P M P$ \& KB Office to organize and activate adolescent reproductive health counseling training and invite peer counselors who are active in Sumenep district, as well as facilitate any adolescent reproductive health counseling activities in the form of facilities and infrastructure.

\section{ARTICLE INFO}

Recived 20 October 2020

Accepted 27 October 2020

Online 29 October 2020

*Correspondence:

Dian Permatasari

*Email:

dianpfik@gmail.com

\section{Keywords:}

Knowledge, Motivation, Adolescent Reproductive Health Counseling, PeerCounselor

\section{INTRODUCTION}

Healthy teenagers are a very valuable national asset for the continuity of development in the future. Thus the health status of adolescents is something that needs to be maintained and improved in order to produce the next generation that is healthy, resilient, and productive and able to compete. According to $\mathrm{WHO}$, the youth group, namely the population in the age range 10-19 years, in Indonesia has a proportion of approximately one fifth of the total population. This is in accordance with the proportion of adolescents in the world where the number of adolescents is estimated at 1.2 billion or about one-fifth of the world's population.

Various interventions have been carried out by both government agencies and community social organizations (NGOs), including the program of the student group concerned with AIDS and drugs (KSPAN), the Youth Family Life Preparation Program (PKBR), the Adolescent Reproductive Health Information and Counseling Center (PIK-KRR). ), and counseling on adolescent reproductive health through the school health program (UKS).

Although many programs have been carried out, the problems of youth are still very concerning. This is supported by the results of the Indonesian Adolescent Reproductive Health Survey (SKRRI), where adolescents claim to have friends who have had premarital sexual intercourse aged $14-19$ years (34.7\% female, $30.9 \%$ male), $20-24$ years old. (48.6\% female, $46.5 \%$ male) (2) Based on the Indonesian Ministry of Health, the number of AIDS cases in Indonesia reported up to December 2011 reached 24,131 cases, of which $45.48 \%$ were adolescents. The number of drug use 
is known to be $1.5 \%$ of Indonesia's population, where $78 \%$ of them are aged $20-24$ years, 800 thousand students and university students use syringes and $60 \%$ of needle users are infected with HIV and AIDS.

One of the causes of the emergence of reproductive health problems among adolescents is a lack of knowledge related to the learning strategies used in providing understanding to adolescents and other factors including attitudes and motivation in adolescents. The direct lecture pattern is considered inaccurate, because this tends to lead to passive adolescents as listeners so that relatively little knowledge is left behind.

The strategy developed by the Indonesian Ministry of Health to increase adolescent knowledge is to use a peer counselor training strategy, a learning pattern that focuses on information from and for adolescents themselves, with this pattern teenagers become more active and existing knowledge comes from their own search efforts. This peer counselor training has been conducted in Sumenep Regency, East Java Province since 2008 with a total of 54 participants. The Adolescent Reproductive Health Counseling Training is held once a year. Based on the results of interviews with counselors conducted by researchers, it was found that there were only 29 counselors who implemented adolescent reproductive health counseling to their peers.

One of the indicators of the success of peer counselors can be said to be successful in carrying out counseling for adolescents if they meet the following indicators: In terms of media that must be mastered by peer counselors, namely 8 family functions, maturity of marriage age (PUP), TRIAD KRR, advocacy skills and IEC, material development as needed; From the activities carried out, namely inside and outside with the form of activities providing information both inside and outside, for example through interactive dialogue on radio and TV, counseling and coaching, counseling, seminar organizers, roadshows to other schools, exhibitions, art performances, using printed media such as wall magazines, posters and electronics such as radio, television, and websites, carry out activities that can attract young people to come, get involved in social activities such as health services, environmental cleanliness and other PopulationBased Life Behavior (PHBK) campaigns, record and report.

The Government of Sumenep Regency through the Community Empowerment, Women and Family Planning Agency (BPMP \& KB) of Sumenep Regency held "Guidance and Facilitation of the Youth Counseling Information Center (PIK$\mathrm{R}$ ) at the District Level of Sumenep Regency" is one way to raise the spirit of youth and institutions that have saturated in the family planning program. Participants in the adolescent reproductive health counseling training were attended by 2 delegates from 27 sub-districts throughout Sumenep Regency, with a total of 66 participants.

The implementation of Adolescent Reproductive Health counseling training at the District level throughout Sumenep Regency is carried out once a year for 1 (day) work or 8 hours of lessons, actually this training is optimal for at least 7 days, but because there are several factors of facilities and infrastructure in Sumenep Regency only 1 day. The aim of peer counselor training is to increase the knowledge and skills of adolescents in the field of adolescent reproductive health so that later they can disseminate it to their friends and in their environment, so that adolescents can avoid things that harm themselves, their families and their environment. In addition, to increase selfconfidence in adolescents in providing counseling to friends who have health problems and other problems that need help in solving them. From the above explanation, it can be assumed that the implementation of adolescent reproductive health counseling has not gone as expected. With one of the impacts of adolescent health problems from year to year in East Java Province, especially in Sumenep Regency, is increasing rapidly and the presence of risky behavior by adolescents will increase the impact or burden of disease that is getting bigger. Therefore, it is necessary to have peer counselors who are trained and have a strong commitment, namely to help peers who have problems or who do not have problems regarding reproductive health, and researchers consider the factors that influence the behavior of peer counselors in implementing adolescent reproductive health counseling. . Some of the factors that can influence include predisposing factors, namely knowledge, skills, motivation and attitudes of peer counselors, enabling factors are the availability of facilities and infrastructure for training, and reinforcing factors including family, teachers and peers. With these three factors, according to L. Green, states that there is not a single behavior or action caused by only one factor. All plans to influence behavior must consider these three causal factors. 


\section{MATERIALS AND METHODS}

This type of research is an analytical study using a cross sectional approach. The data collection method is quantitative. The population of this study were all peer counselors who had received training on Adolescent Reproductive Health in Sumenep District, totaling 66 people. This research was conducted in BPMP \& KB, Sumenep Regency, the data collection instrument in the study was a questionnaire that had been tested for validity and reliability in BPMP \& KB
Pamekasan Regency. The questionnaire was distributed to 66 respondents who were taken by simple random sampling. The dependent variable in this study is the behavior of peer counselors in implementing adolescent reproductive health counseling, while the independent variables are knowledge, motivation, support, and supervision of officers. The data that has been collected is then processed and analyzed quantitatively, in this case the analysis used is univariate analysis, bivariate analysis with Chi-Square and multivariate analysis with logistic regression.

\section{RESULTS}

Table 1 Relationship between knowledge and peer counselor behavior

\section{Peer counselor Behavior}

\begin{tabular}{ccccccc}
\hline \multirow{2}{*}{ Knowledge } & \multicolumn{2}{c}{ Not good } & \multicolumn{2}{c}{ Good } & \multicolumn{2}{c}{ Total } \\
\hline & $\mathbf{N}$ & $\%$ & $\mathbf{N}$ & $\%$ & $\mathbf{N}$ & $\%$ \\
Less & 18 & 90 & 2 & 10 & 20 & 100 \\
Well & 18 & 39,1 & 28 & 60,9 & 46 & 100 \\
\hline
\end{tabular}

Table 2 Relationship between motivation and peer counselor behavior

\section{Peer counselor Behavior}

\begin{tabular}{ccccccc}
\hline \multirow{2}{*}{ Motivation } & \multicolumn{2}{c}{ Not good } & \multicolumn{2}{c}{ Good } & \multicolumn{2}{c}{ Total } \\
\hline & N & $\%$ & N & $\%$ & N & $\%$ \\
Less & 21 & 87,5 & 3 & 12,5 & 24 & 100 \\
Well & 17 & 40,5 & 25 & 59,5 & 42 & 100 \\
\hline
\end{tabular}

\section{DISCUSSION}

Peer counselor behavior in the implementation of KRR counseling, the results showed that of the 66 respondents, 46 (69.7\%) stated that the behavior of peer counselors in the implementation of reproductive health counseling was in a good category, while 30 people (30.3\%) stated that the behavior of peer counselors was not good. According to the Indonesian Family Planning Association 2009, the process of implementing adolescent reproductive health counseling must be preceded by a rapport or approach to clients to break the ice so that clients feel comfortable in raising problems. However, in its implementation, rapport is not carried out so that in the counseling process there is no closeness between the counselor and the client and there is no sense of confidence in the client towards the counselor. There are still many respondents who have poor adolescent reproductive health counseling implementation behavior due to the counselor's lack of knowledge about techniques in providing counseling and the role of a counselor so that peers still do not feel comfort and trust in the counselor.

Knowledge of Adolescent Reproductive Health counseling, based on the results of statistical tests with Chi Square, it is concluded that based on the results of statistical tests with Chi Square, it is concluded that there is a relationship between knowledge and behavior of peer counselors in the implementation of adolescent 
reproductive health counseling ( $p$ value $=0.038$ ). This means that the better the knowledge of a peer counselor about adolescent reproductive health counseling, the better their tendency to implement adolescent reproductive health counseling behavior and conversely the less good the knowledge, the less good the tendency to have adolescent reproductive health counseling implementation behavior. The results of this study are in accordance with L. Green's theory which states that there are three factors that influence behavior change, namely predisposing factors, enabling factors and reinforcing factors. The predisposing factor is the personal preference of a person or group in a learning experience and a certain tendency to behave. Predisposing factors include knowledge, attitudes, beliefs, values and perceptions related to the motivation of a person or group to act.

Motivation, based on the results of statistical tests with Chi Square, it is concluded that there is a relationship between motivation and the behavior of peer counselors in the implementation of adolescent reproductive health counseling. ( $p$ value $=0.036$ ).

This means that the better the motivation of a peer counselor, the greater their tendency to implement adolescent reproductive health counseling behavior properly and conversely the less the peer counselor's motivation is, the greater the tendency for them to have poor adolescent reproductive health counseling implementation behavior. According to Danim, motivation is defined as strength, encouragement, need, enthusiasm, pressure, or psychological mechanisms that encourage individuals or groups of people to achieve certain results according to what they want. In carrying out tasks, motivation is one very important aspect. It often happens that a counselor whose performance is not good enough, is not because of his lack of ability, but because of the absence of work motivation so that he does not try to mobilize his full potential in accordance with the demands of his profession and guidance and counseling services.

\section{CONCLUSION}

Most of the peer counselors' behavior in adolescent reproductive health counseling was 46 people, while 20 people had poor behavior in the implementation of counseling. and have good knowledge, namely 28 people and have motivation of 25 people. This study recommends the Sumenep Regency BPMP \& KB Office to organize and activate adolescent reproductive health counseling training and invite peer counselors who are active in Sumenep district, as well as facilitate any adolescent reproductive health counseling activities in the form of facilities and infrastructure.

\section{REFERENCES}

Apsari, Nur Cita, 2000, Sosialisasi Pengetahuan Kesehatan Reproduksi, Skripsi, Program Studi sosiologi FISP Universitas Airlangga

Azwar, S. 2011. Sikap Manusia dan Teori dan Pengukurannya. Yogyakarta: Pustaka Pelajar.

BKKBN. 2010. Kurikulum Dan Modul Pelatihan Pemberian Informasi Kesehatan Reproduksi Remaja Oleh Peer Educator. Jakarta: Direktorat Remaja Dan Perlindungan Hak-Hak Reproduksi.

BKKBN. 2007. Kurikulum Dan Modul Pelatihan Pemberian Informasi Kesehatan Reproduksi Remaja Oleh Peer Educator. Jakarta: Direktorat Remaja Dan Perlindungan Hak-Hak Reproduksi.

Departemen Kesehatan RI. 2007. Modul Pelatihan Kesehatan Peduli Remaja (PKPR).

Departemen Pendidikan Nasional. 2009. Pedoman Pelatihan dan Modul Pendidikan dan Kecakapan Hidup (Life Skill Education). Jakarta: Departemen Pendidikan Nasional.

Departemen Pendidikan Nasional. 2001. Pedoman Pelatihan dan Modul Pendidikan Sebaya (Peer Education) Dalam Rangka Pendidikan dan Pencegahan HIV/ AIDS di SLTA. Jakarta: Pusat Pengembangan Kualitas Jasmani.

Direktorat Jenderal Bina Kesehatan Masyarakat. 2010. Pedoman Teknik Konseling Kesehatan Remaja Bagi Konselor Sebaya. Jakarta: Kemenkes RI.

Dinkes. 2012. Data tentang PMS-HIV/AIDS. Sumenep.

Dewi Rahayu. 2008. Efektivitas Promosi Kesehatan Dengan Metode Peer Education Terhadap Pengetahuan dan Sikap Mahasiswa dalam Menanggulangi HIV dan AIDS. Diunduh dari http://www.docstoc.com/docs/Downloa dDoc.aspx?doc_id=22446400\&ref_url. Diakses 15 Juni 2011.

Green, Lawrence W., Marshal W. Kreteur. 2000. Health Promotion Planning An Education and Enviromental Approach. London: Mayfield Publishing Company.

Kementerian Kesehatan. 2011. Laporan Kasus Penyalahgunaan NAPZA dan Penderita HIV AIDS Kementerian Kesehatan Republik Indonesia. Diunduh dari situs Kementerian Kesehatan Republik Indonesia. 
Mohammad, Kartono. 1998. Kontradiksi dalam Kesehatan Reproduksi Remaja "Youth Centre", Jakarta: Pusat Perkumpulan Keluarga Berencana Indonesia, BKKBN, UNFPA.

Muadz, Masri M., dkk. 2009. Panduan Pengelolaan Pusat Informasi dan Konseling Remaja (PIK Remaja). Jakarta: Badan Koordinasi Keluarga Berencana Nasional.

Muslim, Imam. 2010. Materi Konselor Sebaya Pusat Informasi dan Konseling Remaja. Badan Koordinasi Keluarga Berencana Nasional.

Notoadmodjo, Soekidjo. 2003. Pendidikan dan Perilaku Kesehatan. Jakarta: Rineka Cipta.

PKBI. 2000. Pusat Informasi dan Pelayanan Kesehatan. Jakarta.
PKBI. 2000. Pusat informasi dan Pelayanan Kesehatan Reproduksi Remaja "youth centre", Jakarta: Pusat Perkumpulan Keluarga Berencana Indonesia.

RI DK. 2003. Materi Pelatihan Pelayanan Kesehatan Peduli remaja. Jakarta.

Sarwono, Sarlito Wirawan. 1994. Psikologi Remaja. Jakarta: PT Raja Grafindo Persada.

Syaefuddin, dkk. 2010. Panduan Pengelolaan Pusat Informasi dan Konseling Mahasiswa (PIK Mahasiswa). Jakarta: Badan Koordinasi Keluarga Berencana Nasional.

Widyantoro., Ninuk, dkk. 2002. Panduan Peer Educator Kesehatan Reproduksi. Jakarta: BKKBN. 